\section{Breeding for Increased Tolerance to Black Root Rot in Strawberry}

\author{
Chrislyn Ann Particka ${ }^{1,3}$ and James F. Hancock ${ }^{2}$ \\ Department of Horticulture, Michigan State University, East Lansing, \\ MI 48824
}

Additional index words. Fragaria $\times$ ananassa, Rhizoctonia fragariae, Pythium spp., Pratylenchus penetrans, methyl bromide

\begin{abstract}
Black root rot (BRR) is a widespread disease of strawberry (Fragaria $\times$ ananassa) that causes the death of feeder roots and the degradation of structural roots resulting in an overall decrease in productivity. Black root rot is primarily caused by Rhizoctonia fragariae Husain and W.E. McKeen, Pythium Pringsh., and Pratylenchus penetrans (Cobb) Filipjev and Schuurmans Stekhoven. A previous study identified varying levels of tolerance to BRR in strawberry cultivars with some having high levels of tolerance. In this study, progeny populations were created to determine the amount of genetic variability for BRR tolerance. Genotypes with high, intermediate, and low tolerance to $B R R$ were crossed in a diallel mating scheme, progeny were planted in Vapam (metam sodium)-fumigated and nonfumigated soil, and were analyzed for yield parameters. The results showed significant differences for both treatment and family, but not for the interaction between treatment and family. Pathogen analysis indicated presence of fungal pathogens and nematodes in both fumigated and nonfumigated soil.
\end{abstract}

Black root rot (BRR) is a widespread disease of strawberry that causes the death of feeder roots and the degradation of structural roots resulting in an overall decrease in productivity (Maas, 1998). By the 1950s, BRR had been reported in many areas of the world (Raski, 1956), and most strawberry researchers now believe that BRR has replaced red stele (Phytophthora fragariae Hickman) as the most serious root disease of strawberry in the northeastern United States (Pritts and Wilcox, 1990).

Many biotic factors have been associated with BRR, with Rhizoctonia fragariae perhaps the most common and widespread throughout the United States and other countries (Abad et al., 1999; D'Ercole et al., 1989; Husain and McKeen, 1963; Maas, 1998; Szczygiel and Profic-Alwasiak, 1989). Various Pythium species have also been identified as causal organisms (Nemec and Sanders, 1970), and Pythium ultimum Trow is considered to be the most common one (Wilhelm, 1998). The root lesion nematode (Pratylenchus penetrans) was first associated with strawberry in the early 1930s (Steiner, 1931), and Townshend (1963) proved it was pathogenic to strawberry by following Koch's postulates.

Although the three pathogens have been separately implicated as the cause of BRR, it is now believed to be a disease complex between the fungi and nematodes. Fungi are

Received for publication 20 Mar. 2008. Accepted for publication 7 June 2008 .

${ }^{1}$ Former graduate student. Current position and address: Research Director, Sakuma Bros., Inc. P.O. Box 427, Burlington, WA 98233.

${ }^{2}$ Professor.

${ }^{3}$ To whom reprint requests should be addressed; e-mail chrislynp@sakumabros.com able to infect areas of the root damaged by $P$. penetrans more easily than healthy tissue, and nematodes move away from roots after fungi invade (Chen and Rich, 1962). LaMondia and Martin (1989) found that the severity of $R$. fragariae infection is raised as a result of infestation by $P$. penetrans.

No completely effective chemical control measures have been identified for BRR in matted row culture. In annual systems, fumigation with methyl bromide and chloropicrin is highly effective, especially where Rhizoctonia predominates (Maas, 1998). However, pathogens ultimately re-establish in perennial systems, and some believe that fumigation can result in an increase in BRR because fumigation also kills beneficial soil microbes, leaving nothing to compete with invading pathogens (Pritts and Wilcox, 1990). Methyl bromide use was completely phased out in 2005, except for critical use exemptions and quarantine and preshipment exemptions (U.S. Environmental Protection Agency, 2007). Strawberry growers and nurseries have been able to qualify for critical use exemptions as no cost-effective chemicals have been identified that provide the same level of control as methyl bromide (Fennimore et al., 2003; Shaw and Larson, 1999).

Developing strawberry cultivars with tolerance to BRR would be an effective control measure. Several studies have been conducted to identify genotypes with tolerance to soil pathogens. Potter and Dale (1994) showed that 'Guardian' had a high level of resistance to $P$. penetrans, and further studies showed considerable variation among 19 cultivars with the four most resistant being 'Pajaro', 'Chandler', Annapolis', and 'Glooscap' (Dale and Potter, 1998). Interestingly, those four cultivars have 'Lassen', a California cultivar, in their background.
In a field primarily infected with Pythium spp., 'Tristar', 'Earliglow', and 'Midway' had the healthiest roots (Wing et al., 1995). However, Rhizoctonia spp. and $P$. penetrans were not in the field and no disease symptoms were observed on aboveground portions of the plants, indicating that disease pressure was low.

Two studies in California that measured leaf number, plant diameter, yield, fruit weight, and fruit appearance on fumigated and nonfumigated soils did not identify any genotypes with strong tolerance to sublethal levels of soil pathogens (Larson and Shaw, 1995; Shaw and Larson, 1996), although a significant interaction between genotype and fumigation was observed in the second study. The authors concluded that lack of fumigation affected all cultivars similarly because the interaction only explained $2 \%$ to $5 \%$ of the variance. However, only a limited representation of the strawberry germplasm grown in the United States was represented in these studies. Only California genotypes were tested in Larson and Shaw (1995), and in Shaw and Larson (1996), nine California genotypes and nine eastern genotypes were used, six of which were from the U.S. Department of Agriculture program in Maryland.

A study in Michigan that used a broader array of germplasm (four California cultivars, 11 eastern U.S. cultivars, and $12 F$. virginiana Duch. $\mathrm{F}_{1}$ hybrids) also identified only modest differences in tolerance based on yield, fruit weight, crown and runner number, and root and crown appearance. Fields used in the study were infested with Pythium spp., Rhizoctonia spp., Idriella lunata P.E. Nelson \& K. Wilh., Meloidognye hapla Chitwood, and $P$. penetrans (Hancock et al., 2001). Although no significant genotype $\times$ fumigation interactions were found, there was a significant source $\times$ fumigation interaction for fruit weight at $P \leq 0.01$ and for yield and runner number at $P \leq 0.10$. The authors concluded that some tolerance might exist in $F$. virginiana that could be used to improve cultivars, because $F$. virginiana hybrids performed better overall than the eastern or California cultivars.

In the most recent study conducted in Michigan, 20 strawberry genotypes were screened for field tolerance to BRR, including old and new cultivars from six North American breeding programs as well as one wild genotype (Particka and Hancock, 2005). The genotypes were evaluated for crown number, number of flowers per crown, yield, and average berry weight in both methyl bromide-fumigated and nonfumigated soil for 2 years. A significant genotype $\times$ fumigation interaction was observed for crown number and yield in both years of the study, explaining $46 \%$ and $26 \%$ of the variance for yield in Years 1 and 2, respectively, and 61\% and $26 \%$ of the variance for crown number in Years 1 and 2, respectively. Interestingly, 'Bounty', 'Cabot', and 'Cavendish', all from the breeding program in Nova Scotia, displayed the highest level of tolerance to BRR. 
These cultivars had not been previously tested for their tolerance to BRR.

In the experiments outlined here, progeny populations were created to determine the amount of genetic variability for BRR tolerance in which the Nova Scotia cultivars Bounty, Cabot, and Cavendish were used as parents along with six other genotypes. Duplicate daughter plants of the progeny population were grown on fumigated and nonfumigated soil and were evaluated for crown number, flower number, and yield.

\section{Materials and Methods}

We chose nine genotypes from the previous study (Particka and Hancock, 2005) to use as parents: three that displayed high tolerance to BRR ('Bounty', 'Cabot', and 'Cavendish'), three that displayed intermediate tolerance ('Guardian', 'Midway', and 'Winona'), and three that displayed low tolerance ('Jewel', LH 50-4, and 'Mesabi') (Table 1). The genotypes were crossed in diallel mating scheme with no selfs, and reciprocal crosses were grouped into the same family. Thirty-two of 36 possible families were generated, because four crosses were not successful and did not produce any progeny (Table 2).

Crosses were made on greenhouse-grown plants in the spring of 2003 by removing stamens with a pair of sharp tweezers and then transferring pollen to the stigma with a camel hair paint brush or fingernail. Pollinated flowers were covered with cheesecloth for $48 \mathrm{~h}$ to reduce the chance of outside pollination. In most instances, fresh pollen

Table 1 . Strawberry genotypes with high, intermediate, and low tolerance to black root rot used as parents in a diallel mating scheme.

\begin{tabular}{|c|c|c|c|}
\hline Genotype & Yr released & Parentage & Origin \\
\hline \multicolumn{4}{|l|}{ High tolerance } \\
\hline Bounty & 1972 & Jerseybelle $\times$ Senga Sengana & $\mathrm{AAFC}^{\mathrm{z}}$, Kentville, NS \\
\hline Cabot & 1998 & $\mathrm{~K} 87-5 \times \mathrm{K} 86-19$ & AAFC, Kentville, NS \\
\hline Cavendish & 1990 & Glooscap $\times$ Annapolis & AAFC, Kentville, NS \\
\hline \multicolumn{4}{|c|}{ Intermediate tolerance } \\
\hline Guardian & 1969 & NC $1768 \times$ Surecrop & USDA-Beltsville, MD \\
\hline Midway & 1960 & Dixieland $\times$ Temple & USDA-Beltsville, MD \\
\hline Winona & 1995 & Earliglow $\times$ MNUS 52 & $\begin{array}{l}\text { Univ. of Minnesota, St. Paul } \\
\text { and USDA-Beltsville, MD }\end{array}$ \\
\hline \multicolumn{4}{|l|}{ Low tolerance } \\
\hline Jewel & 1985 & NY $1221 \times$ Holiday & NYSAES $^{\mathrm{y}}$, Geneva, NY \\
\hline Mesabi & 2000 & Glooscap $\times$ MNUS 99 & Univ. of Minnesota, St. Paul \\
\hline LH 50-4 & - & $\begin{array}{ll}1 & -\end{array}$ & $\begin{array}{l}\text { Native } F \text {. virginiana } \\
\quad \text { from Montana }\end{array}$ \\
\hline
\end{tabular}

${ }^{\mathrm{z}}$ Agriculture and Agri-Food Canada.

${ }^{\mathrm{y}}$ New York State Agricultural Experiment Station.

Table 2. Diallel mating scheme showing the number of progeny generated from each cross $^{\mathrm{z}}$.

\begin{tabular}{lcccccccc}
\hline Genotype & Cabot & Cavendish & Guardian & Jewel & LH 50-4 & Mesabi & Midway & Winona \\
\hline Bounty & 50 & 10 & 19 & 50 & 50 & 8 & 28 & 8 \\
Cabot & & 50 & 50 & 8 & 50 & 0 & 32 & 41 \\
Cavendish & & & 0 & 50 & 50 & 0 & 50 & 50 \\
Guardian & & & & 0 & 14 & 24 & 10 & 5 \\
Jewel & & & & & 50 & 23 & 39 & 50 \\
LH 50-4 & & & & & & 50 & 50 & 50 \\
Mesabi & & & & & & & 8 & 11 \\
Midway & & & & & & & 50 \\
\hline
\end{tabular}

${ }^{\mathrm{z}}$ Note that there were no selfs and that reciprocal crosses were grouped into the same family.

was collected from open flowers for crosses, but occasionally pollen was used that had been previously collected and stored in 1.5$\mathrm{mL}$ Eppendorf tubes at $-16{ }^{\circ} \mathrm{C}$. Fruit were allowed to ripen on the plant and then were harvested for seed collection. Seeds were sown moist, sterilized potting soil and placed in a growth chamber at $4{ }^{\circ} \mathrm{C}$ with continuous inflorescent light until they began to germi. The seedlings were then transferred into growth chambers at $\approx 20{ }^{\circ} \mathrm{C}$ until they reached the four- to six-leaf stage when they were held in a $10 \times 10 \times 12$-cm pots. These natural daylengths and temperatures $(5.5$ to $38{ }^{\circ} \mathrm{C}$ ) until they were planted into a field at the Horticulture Teaching and Research Center in Holt.

On 2 June 2004, the field was fumigated with Vapam (AMVAC Chemical Corp., Los Angeles, CA) (metam sodium) in $1.2-\mathrm{m}$ strips, alternating between fumigated and nonfumigated bands, at a rate of $89 \mathrm{~L} \cdot \mathrm{ha}^{-1}$. The field was planted on 21 June 2004. Plants in each family were evenly divided into five replications, and the plants (hereafter referred to as mother plants) were set on the border ween the fumigated and nonfumigated strips with $1 \mathrm{~m}$ between plants. Beginning on 24 June 2004, two runners from each of the mother plants were trained into the middle of the fumigated and nonfumigated strips, and daughter plants were established. The runners connecting the mother and daughter plants were cut beginning on 1 Aug. 2004, and the mother plants were dug up and removed from the field on 31 Aug. and 1 Sept. 2004. The field received supplemental

from Montana irrigation as needed, weeds were controlled through use of pre-emergence herbicide and mechanical methods, and fertilizer was applied on 10 Sept. at a rate of $1.8 \mathrm{~kg} \cdot \mathrm{ha}^{-1}$ nitrogen.

Plants were allowed to runner freely with sufficient training to keep the runners of each daughter plant separate from the runners of other daughter plants in the field. The number of runner plants produced by each daughter plant was counted on 21 to 28 Oct. 2004 after the first killing frost of the year. Crowns were also counted on each daughter plant and all of the runner plants (crown number), except crown counts and plants counts, were essentially equal because over $90 \%$ of the plants had only one crown as a result of the young age of the planting. The number of inflorescences per daughter plant and all of the runner plants was counted on 23 to 31 May 2005 before flowers were fully open. This number was divided by the crown number to obtain mean number of inflorescences/ crown. The number of flowers per inflorescence were counted on five randomly selected runner plants from each mother plant on 9 and 10 June after all flowers were open and fruit development had begun, and an average flower number/inflorescence value was calculated. Ten fruit were harvested from each daughter plant and the runner plants on 20 to 27 June 2005 and weighed to calculate mean fruit weight. Total yield was calculated by multiplying crown number, number of inflorescences/crown, number of flowers/inflorescence, and mean fruit weight.

Root samples were taken from randomly selected plants to determine presence of fungal pathogens on 15 Aug. 2005 and plant parasitic nematodes on 29 Aug. 2005. For fungal isolation, $\approx 10$ plants were randomly selected from both fumigated and nonfumigated soil from each of the five blocks and kept separate for treatment and block. Plants were dug using a hand spade and were placed in plastic bags on ice then stored at $1.5{ }^{\circ} \mathrm{C}$ until they were processed the next day. Fungi were isolated from roots by washing the root systems in running water and selecting root segments that had visible lesions. The root segments were cut into $1-\mathrm{cm}$ long sections, surface-sterilized in $1 \% \mathrm{NaOCl}$ for $3 \mathrm{~min}$, rinsed three times in sterile distilled water, and were blotted dry on sterile filter paper. The root pieces were placed on selective medium [quarter-strength acidified PDA supplemented with ampicillin $(50 \mu \mathrm{g} \cdot \mathrm{mL})$ and streptomycin $\left.\left(20 \mu \mathrm{g} \cdot \mathrm{mL}^{-1}\right)\right]$ and were transferred to fresh media as needed for identification (Hancock et al., 2001). Fungi were identified based on the morphology of hyphae and of spores (Barnett and Hunter, 1998; Maas, 1998). For nematode isolation, four plants were randomly selected from the front, middle, and back area of each of the five blocks and were kept separate for treatment, block, and area of the field for a total of 120 plants. Soil was also collected from each of these areas for a total of 30 samples. Plants and soil were dug using a hand spade and were placed in plastic bags on ice and stored at $1.5^{\circ} \mathrm{C}$ until they were processed the next 
day. Nematodes were extracted from root tissue following the flask-shaker method, except that a $0.05 \% \mathrm{NaOCl}$ solution was used in place of the ethyl-mercuric-chloride dihydrostreptomycin sulfate solution (Bird, 1971). To make up a 1 -g sample needed, the four-plant samples for a total of 30 composite samples. Nematodes were isolated from soil using a modified centrifugal flotation procedure with nested sieves (Jenkins, 1964).

Model variance components were estimated as a result of fumigation, family, and fumigation $\times$ family treatment interaction and error as in Larson and Shaw (1995). The analysis of variance was conducted using the GLM function of SAS (SAS Institute, Cary, NC). DIALLEL-SAS05 (Zhang et al., 2005), a program based on Griffing's and Gardner-Ebhart analyses, was used to calculate general combining ability (GCA) and $\approx 0.25 \mathrm{~g}$ of roots were selected from each of

specific combining ability (SCA) effects. Because DIALLEL-SAS05 cannot handle missing values, three parents, 'Guardian', LH 50-4, and 'Mesabi', were not included in this analysis to create a complete data set.

\section{Results and Discussion}

Analysis of all the families. In the analysis of variance (ANOVA) of all the families, significant differences were observed for both fumigation and family, but not for the interaction between fumigation and family (Table 3). Overall means for three of the variables measured were higher on fumigated soil than nonfumigated soil. Crown number was $20 \%$ higher, mean individual fruit weight was $9 \%$ higher, and total yield was $26 \%$ higher. Only the number of inflorescences/ crown and flowers/inflorescence were not significantly different between fumigated and nonfumigated soil. In previous studies

Table 3. Analysis of variance of all families for crown number, number of inflorescences/crown, number of flowers/inflorescence, fruit weight, and total yield of strawberry families grown in Holt, MI, on fumigated and nonfumigated soil ${ }^{\mathrm{z}}$.

\begin{tabular}{|c|c|c|c|c|c|}
\hline Source & $\begin{array}{l}\text { Crown } \\
\text { number }\end{array}$ & $\begin{array}{c}\text { Inflorescence } \\
\text { per crown }\end{array}$ & $\begin{array}{c}\text { Flowers } \\
\text { per inflorescence }\end{array}$ & Fruit wt & Total yield \\
\hline \multicolumn{6}{|l|}{ Fumigation } \\
\hline Fumigated & 5.0 & 2.4 & 7.8 & 8.6 & 711.0 \\
\hline Nonfumigated & 4.0 & 2.4 & 7.7 & 7.8 & 526.3 \\
\hline \multicolumn{6}{|l|}{ Family } \\
\hline Bounty $\times$ Cabot & 4.3 & 2.9 & 7.8 & 14.9 & $1,419.9$ \\
\hline Bounty $\times$ Cavendish & 4.1 & 2.7 & 8.3 & 9.2 & 870.3 \\
\hline Bounty $\times$ Guardian & 1.6 & 3.1 & 8.0 & 7.4 & 341.0 \\
\hline Bounty $\times$ Jewel & 2.4 & 3.0 & 8.5 & 9.0 & 541.9 \\
\hline Bounty $\times$ LH50-4 & 7.0 & 2.5 & 9.3 & 3.4 & 580.8 \\
\hline Bounty $\times$ Mesabi & 2.3 & 3.5 & 7.8 & 7.9 & 443.8 \\
\hline Bounty $\times$ Midway & 2.6 & 3.1 & 8.2 & 7.1 & 510.8 \\
\hline Bounty $\times$ Winona & 5.0 & 2.3 & 8.5 & 9.4 & 840.7 \\
\hline Cabot $\times$ Cavendish & 2.8 & 2.4 & 7.0 & 16.1 & 804.6 \\
\hline Cabot $\times$ Guardian & 5.0 & 1.6 & 6.6 & 11.1 & 575.8 \\
\hline Cabot $\times$ Jewel & 2.2 & 2.5 & 7.3 & 12.9 & 445.9 \\
\hline Cabot $\times$ LH50-4 & 9.1 & 2.1 & 8.3 & 4.6 & 761.4 \\
\hline Cabot $\times$ Midway & 1.8 & 2.9 & 7.0 & 8.6 & 365.9 \\
\hline Cabot $\times$ Winona & 4.2 & 2.0 & 6.4 & 13.8 & 794.4 \\
\hline Cavendish $\times$ Jewel & 3.3 & 2.8 & 7.8 & 13.2 & 979.2 \\
\hline Cavendish $\times$ LH50-4 & 6.6 & 2.7 & 8.3 & 4.1 & 578.3 \\
\hline Cavendish $\times$ Midway & 1.9 & 2.9 & 6.7 & 9.2 & 398.8 \\
\hline Cavendish $\times$ Winona & 3.7 & 2.4 & 7.0 & 11.2 & 727.4 \\
\hline Guardian × LH50-4 & 8.5 & 1.9 & 7.6 & 2.8 & 334.6 \\
\hline Guardian $\times$ Mesabi & 2.7 & 2.5 & 7.5 & 8.6 & 490.3 \\
\hline Guardian $\times$ Midway & 1.6 & 4.3 & 7.3 & 6.3 & 315.8 \\
\hline Guardian $\times$ Winona & 2.6 & 3.0 & 6.4 & 9.4 & 412.4 \\
\hline Jewel × LH50-4 & 8.4 & 2.3 & 9.1 & 3.1 & 579.8 \\
\hline Jewel × Mesabi & 3.5 & 2.3 & 7.9 & 11.3 & 795.6 \\
\hline Jewel $\times$ Midway & 2.4 & 3.0 & 7.1 & 7.1 & 449.5 \\
\hline Jewel $\times$ Winona & 2.5 & 2.6 & 7.9 & 9.9 & 544.4 \\
\hline LH50-4 × Mesabi & 6.3 & 2.9 & 8.3 & 3.6 & 564.0 \\
\hline LH50-4 × Midway & 5.5 & 3.0 & 8.3 & 2.7 & 376.5 \\
\hline LH50-4 × Winona & 6.2 & 2.5 & 7.6 & 3.2 & 363.8 \\
\hline Mesabi × Midway & 1.8 & 3.4 & 6.8 & 6.4 & 241.4 \\
\hline Mesabi $\times$ Winona & 3.3 & 2.6 & 6.8 & 11.1 & 665.6 \\
\hline Midway $\times$ Winona & 3.4 & 2.6 & 7.2 & 8.3 & 482.7 \\
\hline Mean & 4.0 & 2.7 & 7.6 & 8.3 & 581.2 \\
\hline \multicolumn{6}{|l|}{ ANOVA } \\
\hline \multicolumn{6}{|l|}{ Significance (P) } \\
\hline Fumigation (Fum) & $* * *$ & NS & NS & $*$ & $* * *$ \\
\hline Block/Fam & $* *$ & $* *$ & $* * *$ & $* * *$ & NS \\
\hline Family (Fam) & $* * *$ & $* * *$ & $* * *$ & $* * *$ & $* * *$ \\
\hline Fum $\times$ Fam & NS & NS & NS & NS & NS \\
\hline
\end{tabular}

zPlots were fumigated on 2 June 2004, the field was planted on 21 June 2004, and data were collected over the next year. Crown number and total yield are expressed per daughter plant and all of her runner plants. Ns, *, **, **** Nonsignificant or significant at $P \leq 0.05,0.01$, and 0.001 , respectively. in Michigan (Particka and Hancock, 2005), mean yield reduction resulting from lack of fumigation was $46 \%$ in Year 1 and $33 \%$ in Year 2. Average berry weight was smaller only in the second year by just $10 \%$, and crown number was reduced by $47 \%$ in the first year and $41 \%$ in the second year (Particka and Hancock, 2005). The lesser reduction in berry weight than crown number in this and previous studies suggests that losses in runner production (and therefore daughter plants and crowns) plays a more important role in yield reduction associated with lack of fumigation than loss of berry size.

Significant differences were also observed between families for all variables measured (Table 3). Mean crown numbers varied from 9.1 crowns for 'Cabot' $\times$ LH 50-4 to just 1.6 crowns for 'Bounty' $\times$ 'Guardian' and 'Guardian' $\times$ 'Midway'. The eight families that had LH 50-4 as a parent had higher crown numbers than all other families. This is not surprising, because LH 50-4 is a wild $F$. virginiana selection and produces a large number of new daughter plants from runners (Hancock et al., 2001).

Mean individual fruit weight varied widely from the largest fruit of $16.1 \mathrm{~g}$ for 'Cabot' $\times$ 'Cavendish' to a low of $2.7 \mathrm{~g}$ for LH 50-4 × 'Midway'. The eight families with the lowest fruit weight each had LH 50-4 as a parent, which is expected because of the small fruit size of LH 50-4.

The number of inflorescences/crown varied significantly across families, but showed less variability than crown numbers or fruit weight. The number of flowers/inflorescence ranged from a high of 9.3 for 'Bounty' $\times \mathrm{LH}$ 50-4 to a low of 6.4 for 'Cabot' $\times$ 'Winona' and 'Guardian' $\times$ 'Winona'.

Total yield varied across families from a $1419.9 \mathrm{~g}$ average for the progeny of 'Bounty' $\times$ 'Cabot' to just $241.4 \mathrm{~g}$ for 'Mesabi' $\times$ 'Midway'. Other high-yielding families were 'Cavendish' $x$ 'Jewel', 'Bounty' $\times$ 'Cavendish', 'Bounty' $x$ 'Winona', and 'Cabot' $x$ 'Cavendish'. Fruit weight appeared to be the factor that contributed most to high yield, because three of the high-yielding families ranked high for fruit weight ('Bounty' $\times$ 'Cabot', 'Cavendish' $\times$ 'Jewel', and 'Cabot' $\times$ 'Cavendish') and the other two were in the middle ('Bounty' $x$ 'Cavendish' and 'Bounty' $\times$ 'Winona'). Crown number contributed more modestly to high yield, with 'Bounty' $\times$ 'Cabot', 'Bounty' $x$ 'Cavendish', and 'Bounty' $\times$ 'Winona' all having midrange crown numbers. The high number of flowers/inflorescence found in 'Bounty' $x$ 'Cavendish' and 'Bounty' $x$ 'Winona' also contributed to high yield.

Analysis of the complete diallel. In the ANOVA used to calculate GCA and SCA among the smaller set of families, fumigation effects were significant for crown number and total yield but were not for inflorescences/crown, flowers/inflorescence, or mean individual fruit weight (Table 4). Similar to the analysis with all of the families, crown number was $26 \%$ higher and yield was $28 \%$ higher on fumigated soil. There were also 
Table 4. Analysis of variance with the smaller set of families for crown number, number of inflorescences/ crown, number of flowers/inflorescence, fruit weight, and total yield of strawberry families grown in Holt, MI, on fumigated and nonfumigated soil ${ }^{\mathrm{z}}$.

\begin{tabular}{lrccccc}
\hline Source & df & $\begin{array}{c}\text { Crown } \\
\text { number }\end{array}$ & $\begin{array}{c}\text { Inflorescence } \\
\text { per crown }\end{array}$ & $\begin{array}{c}\text { Flowers per } \\
\text { inflorescence }\end{array}$ & Fruit wt & Total yield \\
\hline Fumigation (Fum) & 1 & $26.1^{* * *}$ & 0.05 & 0.1 & 17.0 & $1,346,699.6^{* * *}$ \\
Block/Fum & 8 & 1.8 & 0.74 & 1.0 & $16.0^{* *}$ & $167,445.5$ \\
Family (Fam) & 14 & $9.4^{* * *}$ & 0.95 & $4.5^{* *}$ & $79.6^{* * *}$ & $811,099.7^{* * *}$ \\
$\quad$ GCA & 5 & $19.3^{* * *}$ & $2.34^{* *}$ & $11.0^{* * *}$ & $193.7^{* * *}$ & $1,389,329.1^{* * *}$ \\
SCA & 9 & $4.1^{*}$ & 0.16 & 1.0 & $15.0^{* *}$ & $500,359.4^{* * *}$ \\
Fum $\times$ Fam & 14 & 1.4 & 0.44 & 1.0 & 7.5 & $73,205.1$ \\
$\quad$ Fum $\times$ GCA & 5 & 2.5 & 0.46 & 1.2 & $12.8^{*}$ & $122,867.9$ \\
$\quad$ Fum $\times$ SCA & 9 & 1.1 & 0.42 & 1.0 & 5.8 & $49,319.0$ \\
Error & 110 & 1.7 & 0.56 & 0.9 & 5.5 & $105,503.5$ \\
\hline
\end{tabular}

zPlots were fumigated on 2 June 2004, the field was planted on 21 June 2004, and data were collected over the next year. Crown number and total yield are expressed per daughter plant and all of her runner plants. ${ }^{*},{ }^{* *},{ }^{* * *}$ Significant at $P \leq 0.05,0.01$, and 0.001 , respectively.

$\mathrm{GCA}=$ general combining ability; $\mathrm{SCA}=$ specific combining ability .

significant differences among families for crown number, flowers/inflorescence, berry weight, and total yield, which mirrored the full family analysis.

GCA was significant for all variables, and SCA was significant for crown number, fruit weight, and total yield, but not for the number of inflorescences/crown or the number of flowers/inflorescence (Table 4). These results are as expected, because numerous studies on strawberries have uncovered a great deal of genetic variability for most yield components (Hancock, 1999).

Although there was considerable genetic variability observed among families for most of the yield components, there appeared to be little genetic variability for tolerance to BRR. Fumigation $\times$ family interactions were not significant in the diallel analysis as was the case in the analysis with the complete set of families. Similarly, all of the fumigation $x$ GCA and fumigation $\times$ SCA interactions were not significant, except for a fumigation $\times$ GCA interaction for berry weight. This result was surprising because we previously observed significant differences in tolerance among the cultivars used as parents in this comparison (Particka and Hancock, 2005).

It may be that the difference in disease pressure between fumigated and nonfumigated plots was not as great in this study as in the previous one and as a result, made it more difficult to recognize tolerant types. Average yield was $46 \%$ higher as a result of fumigation in the first year after fumigation in the previous study as opposed to $26 \%$ in this study. The fumigated strips in this study were only $1.2-\mathrm{m}$ wide and bordered by nonfumigated strips on each side, so pathogens did not

Table 5. Number of and significance for plant parasitic nematodes in $1.0 \mathrm{~g}$ of root tissue and $100 \mathrm{~cm}^{3}$ of soil from strawberries grown in Holt, MI, on fumigated and nonfumigated soil ${ }^{2}$.

\begin{tabular}{|c|c|c|c|c|c|c|c|c|c|c|}
\hline \multirow[b]{2}{*}{ Treatment } & \multicolumn{6}{|c|}{ Soil } & \multicolumn{3}{|c|}{ Root } & \multirow[b]{2}{*}{$\begin{array}{c}\text { Overall } \\
\text { Total } \\
\end{array}$} \\
\hline & $\begin{array}{l}\text { Root } \\
\text { lesion }\end{array}$ & Ring & Dagger & $\begin{array}{c}\text { Stubby } \\
\text { root }\end{array}$ & $\begin{array}{l}\text { Root knot } \\
\text { (juvenile) }\end{array}$ & Total & $\begin{array}{l}\text { Root } \\
\text { lesion }\end{array}$ & $\begin{array}{l}\text { Root knot } \\
\text { (juvenile) }\end{array}$ & Total & \\
\hline Fumigated & 7 & 141 & 13 & 35 & 82 & 278 & 32 & 115 & 147 & 425 \\
\hline Nonfumigated & 10 & 203 & 144 & 50 & 3 & 410 & 228 & 46 & 274 & 684 \\
\hline Significance $(P)$ & NS & NS & NS & NS & NS & NS & $*$ & NS & NS & NS \\
\hline
\end{tabular}

${ }^{\text {}}$ Plots were fumigated on 2 June 2004, the field was planted on 21 June 2004, and root and soil samples were collected on 29 Aug. 2005.

Ns, "Nonsignificant or significant at $P \leq 0.05$, respectively.
Table 6. Percentage of root samples containing plant parasitic fungi from strawberries grown on fumigated and nonfumigated soil in Holt, $\mathrm{MI}^{\mathrm{z}}$.

\begin{tabular}{lcc}
\hline & \multicolumn{2}{c}{ Treatment } \\
\cline { 2 - 3 } Pathogen & Fumigated & Nonfumigated \\
\hline Rhizoctonia & 9.8 & 11.8 \\
Epicoccum & 9.8 & 7.8 \\
Fusarium & 11.8 & 13.7 \\
Trichoderma & 2.0 & - \\
Alternaria & 2.0 & - \\
Unknown & 11.8 & 19.6 \\
\hline
\end{tabular}

zPlots were fumigated on 2 June 2004, the field was planted on 21 June 2004, and root samples were collected on 15 Aug. 2005.

$\mathrm{sp}$. is generally considered a weak pathogen in strawberries (A. Schilder, personal communication) and has been shown to interact with $P$. penetrans in the BRR complex (Maas, 1998). Overall, 47\% of the root samples containing fungi were from fumigated areas, and 53\% were from nonfumigated areas. In the previous study, both Rhizoctonia sp. and Pythium sp. were found, but Rhizoctonia sp. was more common (Particka and Hancock, 2005).

In conclusion, it appears that pathogen pressure had begun to equalize in the fumigated and nonfumigated plots by the end of the first fruiting season, although positive fumigation effects were still observed on most yield components. The data obtained in this study suggest that genetic improvement in tolerance to BRR will be difficult to achieve, expect perhaps under very heavy pathogen pressure. Part of the difficulty in identifying tolerant types is likely because BRR is a disease complex involving three different pathogens and the relative pressure from these pathogens can vary from year to year and site to site (Wing et al., 1994). Several other studies have also reported limited genetic variation in levels of tolerance to BRR (Hancock et al., 2001; Larson and Shaw, 1995; Shaw and Larson, 1996). The key to finding cultivars that will perform well in BRR-infested soils will be to select in such soils and to not use fumigants in breeding plots.

\section{Literature Cited}

Abad, Z.G., F.J. Louws, and G.E. Fernandez. 1999. Rhizoctonia and Pythium species associated with black root rot of strawberries in North Carolina. Phytopathol. 89:S1 (abstract).

Barnett, H.L. and B.B. Hunter. 1998. Illustrated genera of imperfect fungi. 4th ed. APS Press, St. Paul, MN.

Bird, G.W. 1971. Influence of incubation solution of the rate of recovery of Pratylenchus penetrans from cotton roots. J. Nematol. 3:378-385.

Chen, T.A. and A.E. Rich. 1962. The role of Pratylenchus penetrans in the development of strawberry black root rot. Plant Dis. Rptr. 46: 839-843.

Dale, A. and J.W. Potter. 1998. Strawberry cultivars vary in their resistance to northern lesion nematode. J. Nematol. 30:577-580.

D'Ercole, N., P. Nipoti, and D. Manzali. 1989. Research on the root rot complex of strawberry. Acta Hort. 265:497-506. 
Fennimore, S.A., M.J. Harr, and H.A. Ajwa. 2003. Weed control in strawberry provided by shankand drip-applied methyl bromide alternative fumigants. HortScience 38:55-61.

Hancock, J.F. 1999. Strawberries. CAB International, Wallingford, UK.

Hancock, J.F., P.W. Callow, S. Serçe, and A.C. Schilder. 2001. Relative performance of strawberry cultivars and native hybrids on fumigated and nonfumigated soil in Michigan. HortScience 36:136-138.

Husain, S.S. and W.E. McKeen. 1963. Rhizoctonia fragariae sp. nov. in relation to strawberry degeneration in Southwestern Ontario. Phytopathol. 53:532-540.

Jenkins, W.R. 1964. A rapid centrifugal-flotation technique for extracting nematodes from soil. Plant Dis. Rptr. 48:692.

LaMondia, J.A. and S.B. Martin. 1989. The influence of Pratylenchus penetrans and temperature on black root rot of strawberry by binucleate Rhizoctonia spp. Plant Dis. 73:107-110.

Larson, K.D. and D.V. Shaw. 1995. Relative performance of strawberry genotypes on fumigated and nonfumigated soils. J. Amer. Soc. Hort. Sci. 120:274-277.

Maas, J.L. 1998. Compendium of strawberry diseases. 2nd ed. APS Press, St. Paul, MN.
Nemec, S. and H. Sanders. 1970. Pythium species associated with strawberry root necrosis in southern Illinois. Plant Dis. Rptr. 54:49 51.

Particka, C.A. and J.F. Hancock. 2005. Field evaluation of strawberry genotypes for tolerance to black root rot on fumigated and nonfumigated soil. J. Amer. Hort. Sci. 130: 688-693.

Potter, J.W. and A. Dale. 1994. Wild and cultivated strawberries can tolerate or resist root-lesion nematode. HortScience 29:1074-1077.

Pritts, M. and W.F. Wilcox. 1990. Black root rot disease of strawberry. Cornell Small Fruits Nswl. 5:1-2.

Raski, D.J. 1956. Pratylenchus penetrans tested on strawberries grown on black-root-rot soil. Plant Dis. Rptr. 40:690-693.

Shaw, D.V. and K.D. Larson. 1996. Relative performance of strawberry cultivars from California and other North American sources in fumigated and nonfumigated soils. J. Amer. Soc. Hort. Sci. 121:764-767.

Shaw, D.V. and K.D. Larson. 1999. A metaanalysis of strawberry yield response to preplant soil fumigation with combinations of methyl bromide-chloropicrin and four alternative systems. Hort Science 34:839-845.
Steiner, G. 1931. Tylenchus pratensis de Man on tobacco, tomato, and strawberry. Plant Dis. Rptr. 15:106-107.

Szczygiel, A. and H. Profic-Alwasiak. 1989. Studies on the interaction between nematodes and fungi in infecting strawberry plants. Acta Hort. 256:561-568.

Townshend, J.L. 1963. The pathogenicity of Pratylenchus penetrans to strawberry. Can. J. Plant Sci. 43:75-78.

U.S. Environmental Protection Agency. 2007. Critical use exemption information. Feb. 2008. $<$ http://www.epa.gov/ozone/mbr/cueinfo.html $>$.

Wilhelm, S. 1998. Black root rot, p. 53. In: Maas J.L. (ed.). Compendium of strawberry diseases. 2nd ed. The American Phytopathological Society, St. Paul, MN.

Wing, K.B., M.P. Pritts, and W.F. Wilcox. 1994. Strawberry black root rot: A review. Adv. in Strawberry Res. 13:13-19.

Wing, K.B., M.P. Pritts, and W.F. Wilcox. 1995. Field resistance of 20 strawberry cultivars to black root rot. Fruit Var. J. 49:94 98.

Zhang, Y., M.S. Kang, and K.R. Lamkey. 2005. DIALLEL-SAS05: A comprehensive program for Griffing's and Gardner-Eberhart analyses. Agron. J. 97:1037-1127. 